I Universidade Federal Fluminense (UFF), Programa de Pós-Graduação

em Comunicação, Niterói, RJ, Brasil

barros.carla@uol.com.br

https://orcid.org/o0oo-0003-4037-1060

Carla Barros ${ }^{\prime}$

\title{
NOT EVEN THE SKY IS THE LIMIT: THE MEANINGS OF CONSUMPTION AND THE DYNAMICS OF SOCIAL MOBILITY ON THE @blogueiradebaixarenda PROFILE ON INSTAGRAM AND YOUTUBE
}

Conventional economic thinking in relation to poverty is situated within a wider field of representations that associates "resource scarcity" with "subsistence economies." In this view, poor and indigenous people live in an eternal "fight for survival" in hostile environments governed by "material shortage." An automatic association is made in this explanatory model between "basic needs," "privations," "scarcity" and "the fight for survival." If the primordial characteristic of consumption is choice, then the presupposition is that economically less-favoured classes do not practice the act of choosing, being guided instead by a logic of lack and material shortage. Sahlins (I979) developed a powerful critique of utilitarianism, understood as the idea that individuals follow their own best interests through a logic of maximizing means/end relations, and that all human cultures are thus formed through practical activity and utilitarian interest. He rejects the notion that human cultures are formulated through practical activity, calling attention instead to how the cultural order is constituted within the field of meaning.

The historical disinterest in the consumption of popular classes in the social sciences is partly due to the prevalence of this logic of "lack" and the "fight for survival," which in practice removes the structuring symbolic and cultural dimension from the phenomenon. As Barbosa (2004: 62) observes, the study of consumption in Brazil appeared much more within a vision of "losses and absences" than one of "gains and positive changes". 
Indifference to the topic gradually dissipated. A pioneering landmark was the publication in I985 of the book Magia e capitalismo (Magic and capitalism) by Everardo Rocha. In this work, the author analyses consumption as an ideal means to understand social relations in the contemporary world, presenting an analogy between the rationale of advertising and totemic logic. From the second half of the 200os, ethnographic studies aligned with the field of the anthropology of consumption began to emerge, expanding the field of research. A common characteristic of these works has been to extricate consumption from its position of mere subordination to the sphere of production, posing it as a crucial element of symbolic and social reproduction. A complex phenomenon, a producer of meanings, communicator of alterities, localizations in society, and a mediator of relations with other spheres of the social.

One tendency in these studies on consumption among low-income groups has been to observe the phenomenon as an expression of distinction and emulation, supported primarily by the contributions of Bourdieu (I979a) and Veblen (I970), respectively. Although these are important analytic frameworks to be mobilized, this field of investigations needed to be expanded through research into specific situations that reveal other dimensions of such a nuanced theme. Some of these studies have emphasized the act of consuming as a desire for belonging, as Silva (2010) points out in her ethnography showing how mobile phone use expresses a mode of access to wider society, a "being-in-modernity." Other works have demonstrated that a poverty of resources is not synonymous with material scarcity (Barros, 2007; Scalco \& Pinheiro-Machado, 20Io; Castro, 20I6). On the contrary, the materiality of the groups studied provided an enormously rich source of cultural meanings, their budgets allocated to a diverse range of consumer items very distant from the narrow logic of "subsistence items." Among middle- and upper-class sectors of Brazil, in parallel with academic studies, there has been a moral condemnation of the profusion of "out-ofplace" objects among the popular classes, shown in the purchase of expensive mobiles and smart TVs. An expansion of material culture apparently inconsistent with the economic circumstance of scarce resources.

Thus, learning about the behaviour of specific social groups is a privileged form of mapping modern-contemporary culture. This involves comprehending consumption as a creator and maintainer of social bonds, a classifier of identities, a means of expressing subjectivities, a mediator of society's fundamental values, seeing the phenomenon, in sum, as an articulator of systems of categories with an expressive and symbolic function.

It is in this context that the interest emerges in analysing the @blogueiradebaixarenda (@lowincomeblogger) profile as a marker of important questions relating to the consumption of low-income groups. Very popular in Brazil on social media sites like YouTube, Twitter and Instagram, the profile sets out to publicize the "low-income lifestyle," a theme in which consumption occupies a prominent place. 
Since the research was undertaken in digital environments, it is worth recalling the position of Miller and Slater (2004) concerning the inadequacy of any a priori distinction between online and offline life. The authors, who studied the relations lived in cybercafés in Trinidad, pointed out that this distinction should not be established as neither a methodological or an analytic starting point for research: on the contrary, it is contingent, since in some contexts people establish clear boundaries in their lives for each of these spheres, while for others the distinction is irrelevant or simply never made.

The research forms part of the field of anthropological studies that advocates exploring consumer activities as important everyday phenomena of cultural creation (Miller, I987). In the discussion on material culture more specifically, Daniel Miller took inspiration from Hegel's reflections to suggest that material culture is a specific mode of externalization of industrial society. Goods produced on a large scale and in huge variety are reappropriated at the level of consumption when they lose the anonymity present in the domain of production to be humanized, completing the trajectory from merchandise to privately-owned item. The author seeks to unravel the meanings and implications of this proliferation of material goods making up industrial society by identifying the specificity of its "progress" through the continual emergence of exterior forms in the form of goods. Through the process he calls "objectification," person and object become connected after consumption as subjects reveal their choices, worldview and aesthetic sense through their uses of the objects.

As Kopytoff (2008) emphasizes, the object-person separation is highly particular and limited in scope, although lived in western society as though it were a universal phenomenon. Objects, in their relations, always constitute classificatory systems in which we situate and hierarchize them.

The article thus sets out to comprehend the meanings of consumption in the @blogueiradebaixarenda profile on the online social networks Instagram and YouTube, considering the perceptions concerning materiality and their articulations with the dynamics of social mobility in an extremely hierarchized society like Brazil's. Its aim is to analyse which elements make up the "lowincome lifestyle" (lifestyle baixa-renda) as a native category within the context of "digital influencers." The research was developed through the analysis of the posts ${ }^{\mathrm{I}}$ made by the @blogueiradebaixarenda profile on the Instagram and YouTube social networks from the beginning of the author's online presence to February 2020. Hashtags (\#) were also included since they comprise native classifications. As well as constituting a way of grouping messages that allow searches for specific content on social media, these symbols are of direct interest here since they are created and tagged by the users themselves, allowing the classificatory logics of the actors to become apparent. Hashtags can also express feelings, ideas or humoristic contents when the intention is not only to help users find topics. 
The field procedure adopted was online observation, a particular modality of observational research (Flick, 2004) conducted in the digital environment, accompanying social dynamics on the online platforms without interacting with users. Selected images have been included in the text without the need to camouflage people's faces since the @blogueiradebaixarenda on Instagram is a public, not private, account. Hereafter, Blogueira de Baixa Renda (Low-Income Blogger) will be abbreviated to BBR.

\section{THE LOW-INCOME LIFESTYLE}

The BBR profile present on digital platforms was created by Nathaly Dias, 27 years old, a resident of the Morro do Banco community in the East Zone of Rio de Janeiro city. In her posts, she recounts her upbringing in a family with severe economic difficulties until her enrolment on a university course where she studies Business Administration with a full scholarship.

Nathaly is active as a content creator on the social media platforms ${ }^{2}$ Instagram (I 24,000 followers in February 2020) and YouTube (I60,000 subscribers in February 2020) with the proposal to divulge, in her own words, the "lifestyle of the poor" and raise the awareness of baixa-rendinhas - "low-incomers," the nickname given to her followers - that belonging to a particular social class is not an impediment to social mobility.

In her profile presentation on Instagram, Nathaly declares that she is "(re) signifying influence." In an interview, she explains how she perceived that the universe of so-called digital influencers ${ }^{3}$ was formed largely by women who divulge luxurious lifestyles with a level of consumption very distant from the everyday world of most of the population. From this perception emerged the idea of exploring "low-income lifestyle," (re)signifying influence by adopting a more realistic tone matching the experience of the popular classes in Brazil. ${ }^{4}$

One of the main theoretical references for the concept of "lifestyle" is Bourdieu (I979a), who suggested that different classes exhibit different lifestyles according to the place occupied in the social hierarchy. 'Taste,' as a propensity to appropriate certain objects and practices, appears in a set of distinctive preferences expressed in elements like furniture, clothing and bodily hexis, among others. The emphasis in this article is on the idea of lifestyle as a native category, seeking to analyse its constitutive elements and meanings present in the context of the BBR profile.

It is worth emphasizing that the polarity between low-income and highincome lifestyles appearing in the case analysed here can be inserted in a debate on imitation and distinction developed by various authors from the social sciences like Veblen, Simmel, Bourdieu and McCracken. In this context, the "trickle-down" theory stands out, discussed by Veblen (I965) and Simmel (I957) and carefully revised by McCracken (I988). According to this theory, the entry point for a fashion object should be the society's highest class: from there, 
the other classes would successively copy what they saw above within a logic of imitation on the part of subordinates and differentiation on the part of the elite, leading to a constant renewal of the fashion circuit. As McCracken (I988) argues, the behaviour of the groups at the base of the pyramid cannot be reduced to just a single possibility as trickle-down theory suggests. Alongside the imitation and assimilation of what is created by the elites, the popular classes also reject many of these tendencies or reformulate them according to their own codes. In the present article, I eschew the idea of trickle-down because of the element of generalization present, which presupposes a passive behaviour among subordinate classes. In this context, alterity presents various layers in which the affirmation of the singularity of class coexists with the desire for practices of consumption related to a more individualist set of ideas (Dumont, I972), as we shall see later.

Nathaly Dias's activities as a content creator on the internet began with the creation of the @blogueiradebaixarenda profile on Instagram on October 3 , 20I7. The choice of this social network to begin her career as a blogger had a declared motive. Instagram is known for the significant presence of images of luxury and ostentation in numerous profiles, especially those of digital influencers who divulge lifestyles connected to high patterns of consumption. Similarly, this appropriation connects to a practice found on the pinboards of Pinterest, another online social network where the visualization of goods and settings is stimulated by "daydream" mechanisms as a mode of "contemplative digital materialism" (Barros, 20I5). As a theoretical concept formulated by Colin Campbell (200I: I 28), the daydream is characterized by the use of the imagination for pleasure through the search to anticipate a real event. The author calls this process "self-illusory hedonism", wherein the individual is the artist of the imagination and dreams, taking images and rearranging them into unique products. This is identified as a legitimate modern faculty - the creation of an illusion known to be false but felt to be true. In this "hedonism in another world," different from traditional hedonism, the unknown is a field open to innumerable and unlimited possibilities. Desire here is allocated in the unknown, itself a pleasurable activity. Faced with an elitized universe of consumption, the BBR profile is explicitly opposed, offering a self-described "feet on the ground" approach that seeks to inject doses of "reality" in each post. "Dreaming" is also a constant theme but based on the deglamourized day-to-day life of the blogger: "I fight every day for an internet I always wanted to see, REAL."

Baixa-renda, low-income, is an adjective used on the profile to encompass a universe of situations, forms of consumption, modes of being, sociabilities and moralities. How to travel without spending much, how to paint the walls at home, how to make purchases in a controlled fashion, how to stop procrastinating, how to cook low-income meals: these are some of the themes of the posts whose hashtags frequently include the adjective: \#casalbaixarenda (\#lowincomecouple), 
\#faxinabaixarenda (lowincomecleaning), and many others. BBR's husband and mother also gravitate around the same designation, their profiles on Instagram named @maridobaixarenda (@lowincomehusband) and @maedablogueira (@bloggermother). Her husband, Guilherme 'Stu,' participates constantly in the activities involving the BBR profile - he records the videos, interacts verbally during the recordings, and features in many of the images published online.

Following the success on Instagram, BBR set up a YouTube channel and began to attract the attention of the business market, becoming recognized as an influencer of the "class C public." This classification of a target public was how the market labelled consumers, emerging from the poorest strata, who experienced economic upward mobility during the Lula governments. With the improvement in living conditions, marketing professionals identified this sector as a prime target for their campaigns, undertaking market research and creating new forms of persuasive advertising (Moura, 20I5). In this scenario, Nathaly Dias appears as an important "digital influencer" close to the popular classes, eventually contacted for a variety of marketing projects with companies like SERASA Experian, Gol, Superdigital MEI, Editora Intrínseca and the Unicesumar faculty where she studies. The advertising posts - also called publi (from the Portuguese publicidade) and indicated on her profile with the hashtags \#publi and \#publibaixarenda - possess a strong element of financial education and professional growth within a context of encouraging social mobility.

One of these partnerships, formed with the company Superdigital MEI, illustrates how BBR poses herself as an example for anyone seeking upward social mobility through work. The company sponsored a mini-series ${ }^{5}$ on favela entrepreneurs to advertise its banking business to people wanting to professionalize in which BBR appears selling bolos em pote (pot cakes).

The contents published on her profile have a strong motivational aspect, seeking to "inspire," as in the posts: "I came from the bottom of the well, so low there was no further to go, and yet I managed to climb up, I'm raising myself up again, building something beautiful. Lots of things that will help and encourage you," "Woke up for what? Woke up to win!" or "Let's wake up every day to win and bash the sadness away, after all we wake up every day to fight." The response from her followers is typically enthusiastic, ranging from praise "you're beautiful, you're the best..." and "best blogger!" - to thanks for the motivating messages. Also observable is the legitimization of her proposal to publicize and represent low-income sectors, as in the post: "this Instagram is marvellous, I'm feeling represented

The Morro do Banco community where BBR lives is visible in numerous posts, as in the YouTube video Tour of the favela | Morro do Banco. ${ }^{6}$ In this way, the "effect" of the social conditions, circumstances and constraints on individuals is underlined. The emphasis on the physical, social and human "geography" of the favela as a place of origin expresses a feeling of belonging to a reality perceived 
as highly active in the creation of aspects like behaviours, sociability, life conditions and sensorialities. In the latter field, one element that is frequently emphasized is the high volume of noise present in the community, whether the loud voices of neighbours or the sound of a passing motorbike. The comments in response to these posts tend to confirm a particular conditioning of life in the community: "that's what it's like among the low-income," Nathaly remarks in one video, as though apologizing too for something perceived as undesirable.

The embarrassment shown with the emphasis on the faltas (lacks, wants, deprivations) that make life in the favela precarious closely reflects the construction of these communities as problematic places from their first emergence in Rio de Janeiro at the end of the nineteenth century (Valladares, 2005). Since then, serious social problems have been associated with these urban spaces, depicted as hotspots of extreme poverty, filth and insalubrity, an example of the country's housing crisis and the genesis of social violence (Machado da Silva, 2002). The precarious living conditions in her local community and the strategies available to confronting and find a solution to this adversity are, therefore, themes widely present in BBR's profile.

But although the "problem favela" appears in some of her content, this is not the overall tone of the posts. Superimposed is the perception of a space of morality in which conditions can shape noble values like perseverance and persistence. There is a valorisation of community residents, emphasizing their adaptability to scarce resources ("poor people get by"), their creativity and profile as "warriors" in the "battle" of everyday life, a feeling that can be expressed in the idea of superação, "overcoming." In this emphasis, there is no feeling ashamed of the favela - no social construction of the locality as a "problem place" - but instead pride over a sense of belonging, expressed, for instance, in the slogan on the t-shirt that appears in one photo published on Instagram, taken in front of the window with the community in the background: respeita minha história, respect my history.

In this context of valorising the favela's residents, BBR poses herself as an example to inspire others, emphasizing her trajectory from a childhood of poverty, the daughter of a housemaid who raised her two children alone, to her present life as a university student and digital influencer. The emphasis is on effort, tenacity, formal education and honest work to achieve a new social place.

The phenomenon of consumption occupies a prominent place in BBR's social media publications. The low-income lifestyle, in her proposal to show popular class "life as it is," is represented in posts like "poor people's breakfast," "going to the market with 30 reais" or "monthly shop at the Guanabara Anniversary."

Among the various themes published in this context, cleaning is frequently present, appearing though some cleaning activity being undertaken or the display of recommended products, as in: 
I love this product. It's for general use but I throw bleach on everything, rinse and wipe with this just to leave a nice smell. And aaaaaaaaaah how I love the smell, tomorrow my bathroom will still be like it's just been cleaned.

RE A L O VE

L.r. \#myhome \#tidyhouse \#cleanhouse \#cleanbathtoom \#myapt \#poorbutclean \#housewife

Source

<https://www.instagram.com/p/BicoXSWFOXk/?utm_source=ig_web_copy_link>

Discussing the practice of washing clothes in Brazil, Barbosa (2006) has shown how notions of disgust and pollution underlie the classificatory system operating in the country. As Douglas (I976) proposed, cleanness is found at the core of the symbolic reproduction of order. The Brazilian system, as Barbosa points out, presents such complexity that it presupposes a total and radical separation between different categories of clothes, distinguishing those of the body from those of the home, based on the principle of pollution. The central logic of this system is to prevent clothes that have had contact with certain types of persons and things, taken to be distinct in nature, from mixing with others, revealing how notions of pure and impure are articulated with an important moral code.

In the case of low-income groups, the negative connotation of poverty may be compensated by many forms of care with cleanness, expressed in the popular saying "I'm poor but clean." Duarte (I986) had already called attention to this compensatory dynamic also operative in the dimension of work with the maxim "I'm poor but hardworking."

Thus, the emphasis on cleanness can be experienced as a way of dealing with the stigmatization of poverty as a polluting element (Douglas, I976), working to loosen class segregations. In the BBR profile appear both the hashtag \#poorbutclean, and the variation \#oldbutclean. In one of the Instagram posts, this latter expression appears alongside a photo showing a clean oven with comments expressing playful regret, since it was soon due to be dirtied again by her mother who would be using it "on loan."

Observing the set of hashtags, a profusion exists around the themes of cleaning and household work, like: \#cleanoven \#cleankitchen \#tidyhouse \#springclean \#housewife \#myapt \#myhome \#cleaning \#decor \#marriedlife \#homeblogger \#eletrolux \#homeneighbours

Identification with the cleaning theme led to the first commercial partnership of the BBR profile with the company Limpano, which sent her a basket of their line of products: 


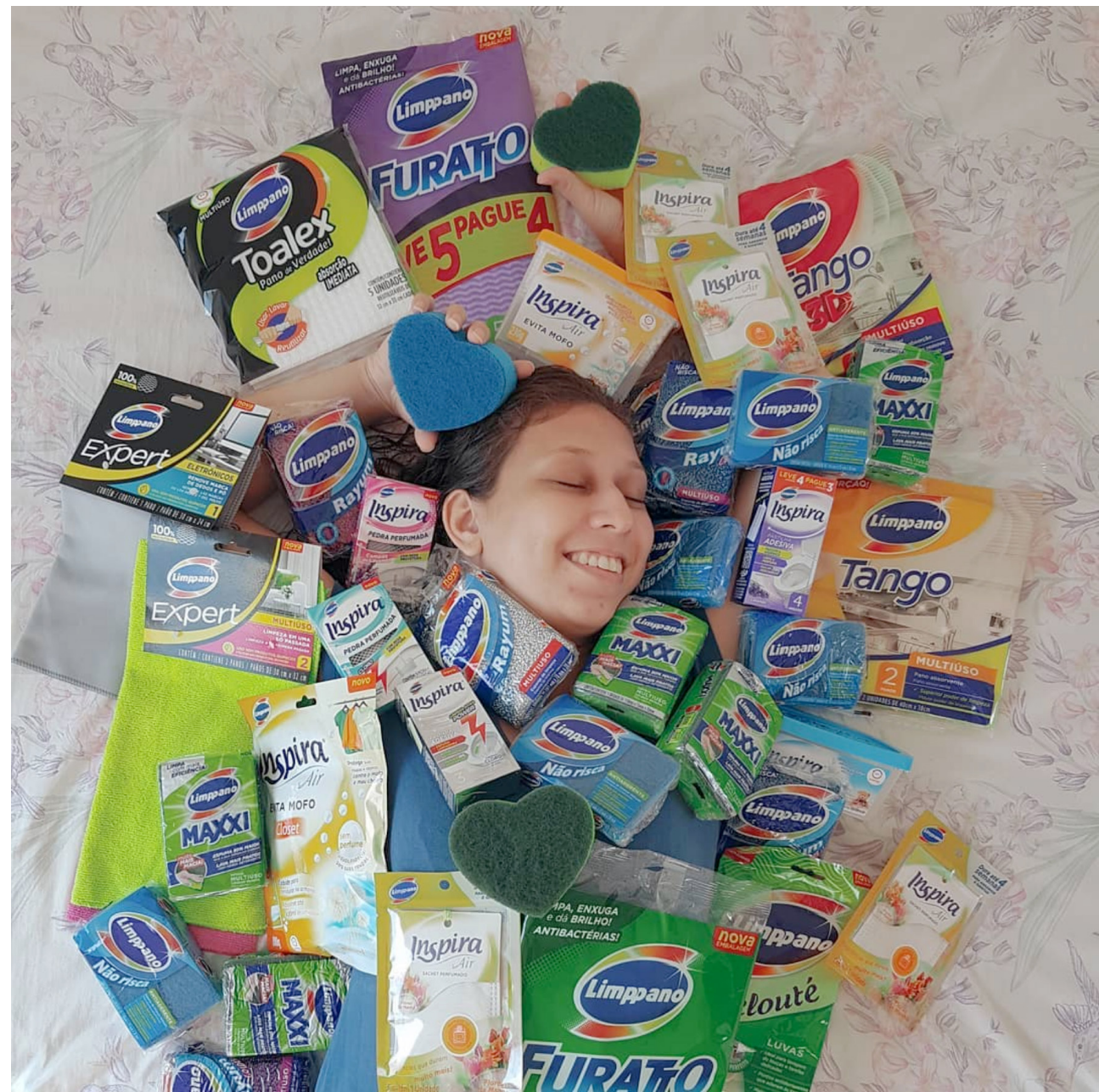

Figure I

<https://www.instagram.com/p/Bk-yoyNlsaf/?utm_source=ig_web_copy_link>

Cleaning, as well as appearing as an element that serves in the construction of a positive identity in the context of poverty, also emerges in another context where the 'basic' encounters a lifestyle, as in the following post:

When your colour palette matches the supermarket offer This is my blogger way of being... I can't see washing powder without wanting some.

\#blogger \#organisedhome \#cleanhome \#myapt \#myhome \#supermarket housewife \#scrubbing \#cleaning \#cleanclothes \#lookoftheday 


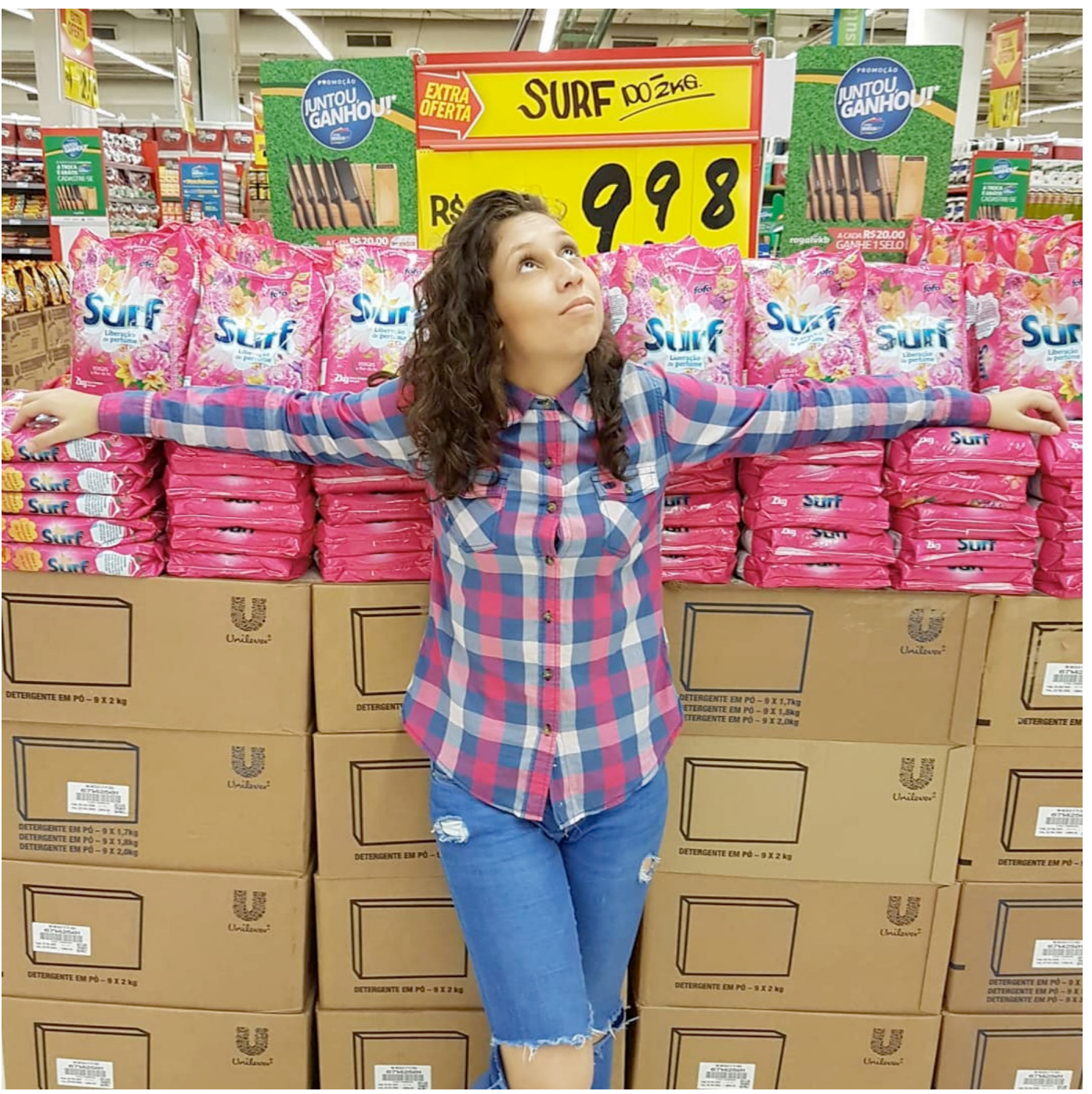

Figure 2

<https://www.instagram.com/p/BlTLkPvl88n/?utm_source=ig_web_copy_link>

The hashtags \#scrubbing and \#cleanhome are found side-by-side with \#lookoftheday, highlighting the aesthetic and performative aspect of the dissemination of lifestyles in the online environment, enchanting the most banal tasks of everyday life. Similarly, the packed lunch - the stigmatized symbol of belonging to the popular classes - appears in a decorated frame in another post where the combination of a 'basic' item and an aesthetic frame is stressed. 
Thus, the negative connotation of poverty is compensated by the lowincome lifestyle, which softens this condition by passing to another plane on which the idea of lifestyle relates to an act of choice (Slater, 2002), as well as something that can be observed, admired and emulated.

In another post, BBR seems to be smiling as she cleans the bathroom, wearing shorts and a bikini top, accompanied by the hashtags \#myhome, \#myapt, \#cleaning, \#lookoftheday_and \#housewife and the phrases: "Real look of the day: CLEANING. That's what accessible bloggers do SMILING EMOJI." The hashtag \#lookoftheday, common on the profiles of a wealthy universe, is inserted in the context of the "feet on the ground" reality of the baixarenda (low-incomers). Her followers react by endorsing her place as a blogger disseminating a particular lifestyle and trends, as in the humorous comment: "Bikini-clad cleaning... I've discovered a trend! That's what bloggers do! Haha-

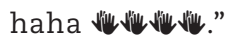

As well as cleaning, other regular themes in the publications are meals, ${ }^{8}$ products recently bought for the home, along with kitchen utensils and decorations, items and goods photographed in stores as desired objects of future consumption, and spaces in the apartment. In one of the posts, 9 the "real life" dimension merges with the "daydream" (Campbell, 200I). Under the heading “TABLE I'D LIKE TO HAVE VERSUS TABLE I'LL BE ABLE TO BUY," the publication displays two photos, one the table that BBR says she has the funds to buy, the other the product she wants. As well as cataloguing the purchased or donated items found in her home, the profile also registers the desired objects of consumption, when the dream component mixes with the recorded materiality.

The purchased or desired objects are combined with dreamt or still immaterialized goods like the "imaginary sofa":

Testing my imaginary sofa

I haven't a clue when I'll manage to buy one, right, but I'm determined and even if it isn't a priority, I've already constructed everything in my mind. Have I ever told you that I've never had a sofa? In fact, I've never had a LIVING ROOM! That's why I'm so eager to have one.

'Wish' items that I want and will get in 2019:

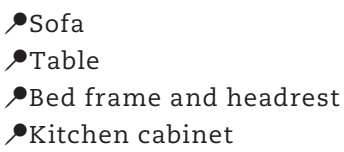

And who knows, maybe a television for my living room? DREAMING IS GREAT, I'M ADDICTED

Note: I bookmarked Magalu [online store], maybe it'll happen! HAHAHAHAHA 


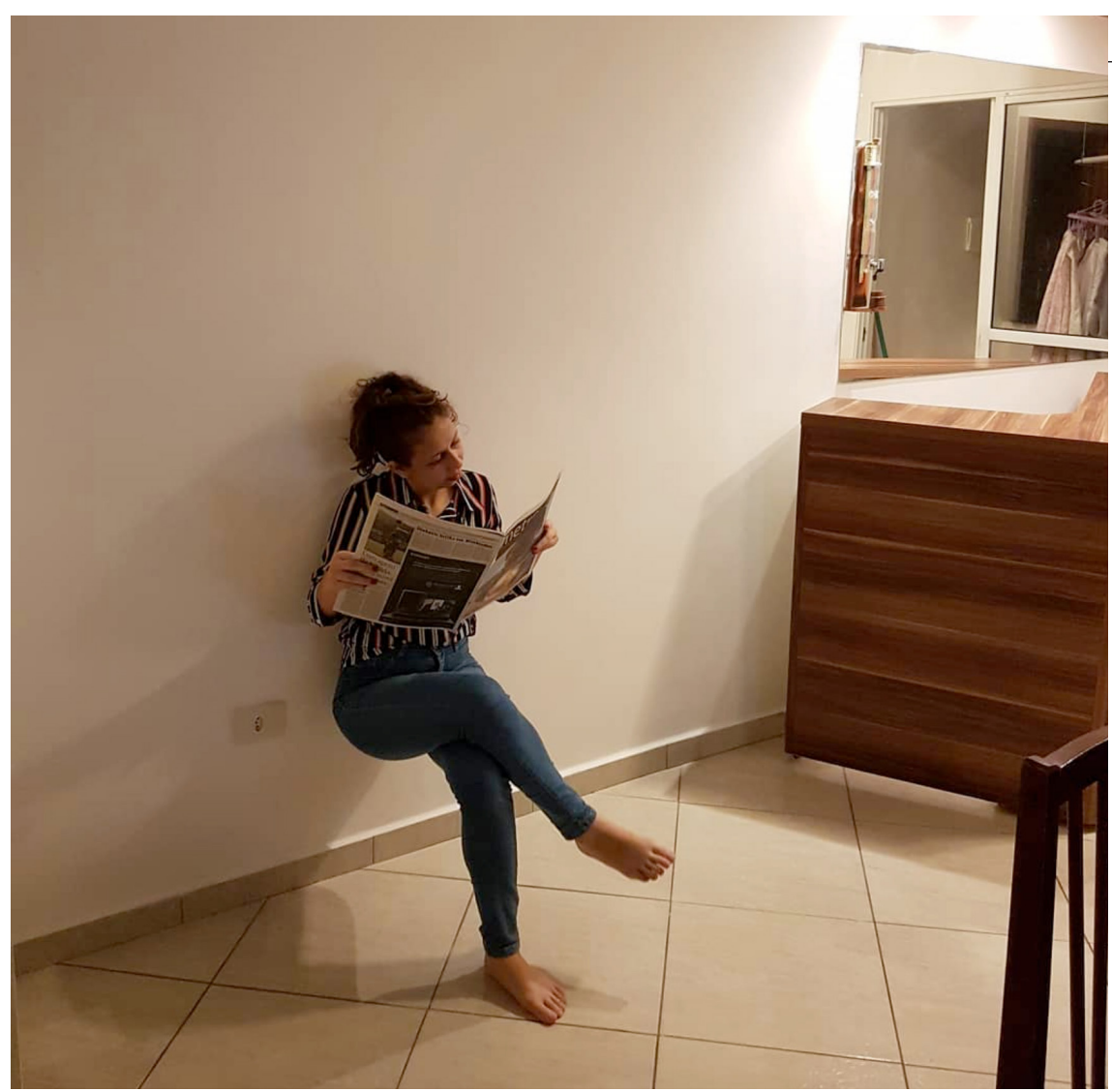

Figure 3

Oે

<https://www.instagram.com/p/BmbxvizhNWI/?utm_source=ig_web_copy_link> 
When items from her home are shown in the posts, whether public or not, they are accompanied by information on the retailer and price, indicating a good buy:

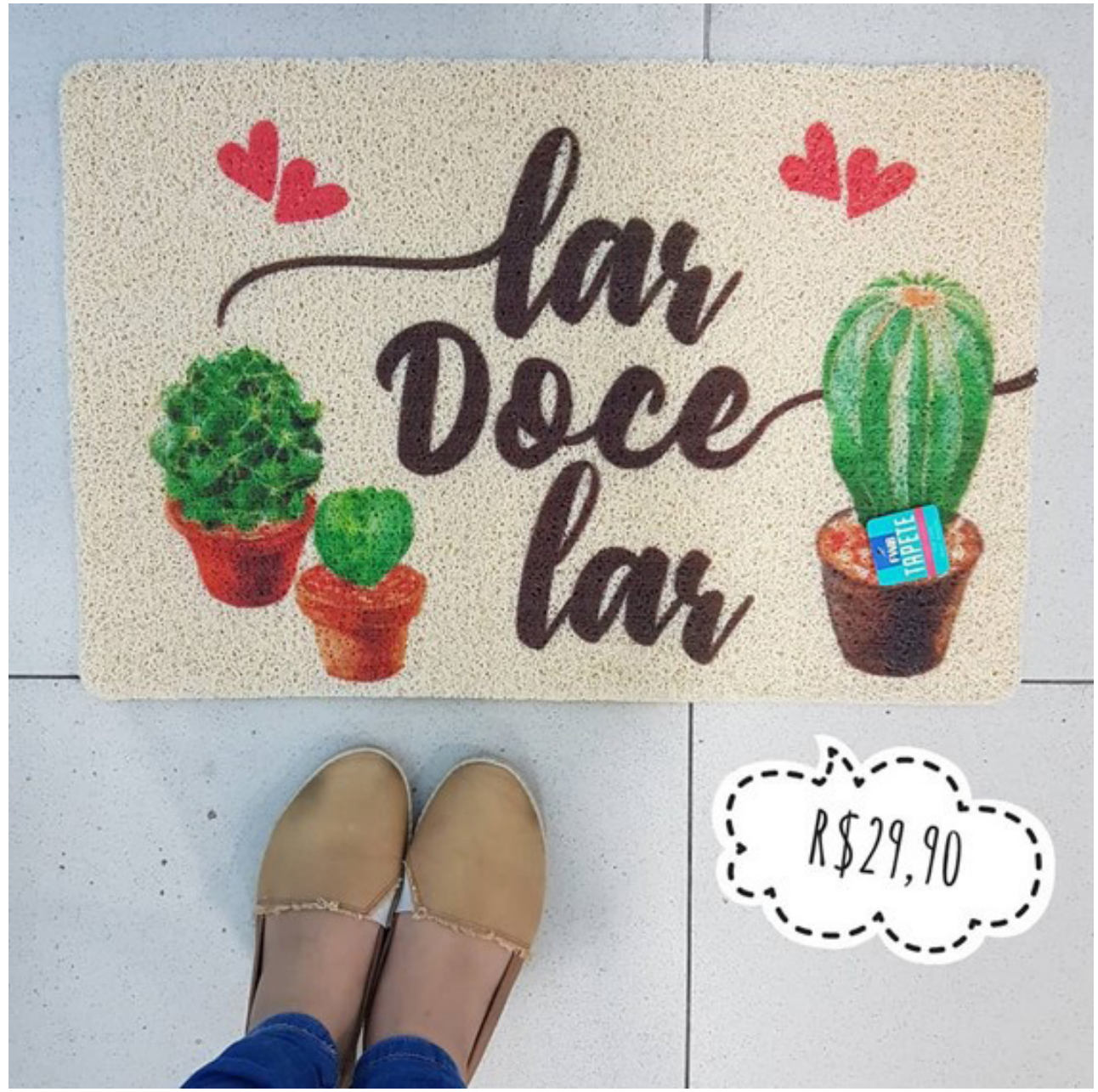

Figure 4

<https://www.instagram.com/p/BmbxvizhNWI/?utm_source=ig_web_copy_link> 
Comments from her followers on this type of post are typically enthusiastic about the accessible price and/or beauty of the item, as well as its choice as an object of desire: "One more thing saved, one more shop that will end up with my money at the end of the month... that's not gonna work! @blogueiradebaixarenda 0 을"

In the lifestyle propagated by BBR, evinced in the shrewdness of knowing how to spend money well, which does not mean just buying the cheapest item, but also knowing something "is worth it" or "cheap end up expensive." As commented earlier, an important element of this idea of "lifestyle" is its aesthetic aspect, combined with the question of good value. This is perceptible in the declaration: "Wow, I'm impressed by how you can have a well-decorated home spending little."

The content follows the tone of other profiles propagating lifestyles through the use of terms like "outfit" and "look," only in a "real" and "accessible" context, words frequently used by BBR, as in the hashtag \#accessiblebloggerlook.

Alongside the elements of material culture, the low-income lifestyle encompasses sociabilities, modes of feeling, moral values, attitudes and stances towards events. In the case of BBR, the presentation of her impressions is pervaded by a light-hearted humour in response to difficult events. Everyday situations are depicted with an ironic outlook that alleviates the scene:

I took advantage of the fact my cupboard door fell off (SEE THE STORYLINE) 오 to clean my shelves.

The bottom shelf is where I keep my HUGE PILE of plates. 2 large, 2 deep and 2 for dessert, there's no space for more, it's all there is, and it meets the basics. THE ONLY THING IS, NO MORE THAN TWO PEOPLE AT A TIME HAHAHAHAHA

Source

$<$ https://www.instagram.com/p/BmWulolBP5B/?utm_source=ig_web_copy_link>

The hashtags are also a vehicle for this good-humoured tone, as appears in a post showing BRB on a work trip, stepping out of a hotel swimming pool: \#hotel \#trip \#sp \#rj \#lowincomeblogger \#dontknowhowtoswim \#mermaiding \#diva \#accessible.

Source

<https://www.instagram.com/p/BqYNUe-hEoZ/?utm_source=ig_web_copy_link>

The strong solidarity among peers also forms part of this conception of the low-income lifestyle, exemplified in the fitting out of the new apartment, all done with items donated by friends and family. In turn, this way of dealing with events is expressed in the values of persistence and hard work. The act of "fighting" emerges as a response to everyday challenges, which to be met require a determined and positive approach: "Let's wake up everyday to win and bash away sadness, after all we wake up everyday to fight." 


\section{SOCIAL MOBILITY}

As we have seen, the BBR profile initially emphasized her "poor condition," which has a social and physical "place" - the favela - idiosyncrasies, behaviours, a profile: in sum, particularities to be recognized. On another level, though, a call is made to leave behind the fatalism of poverty in favour of the fight for social mobility, as evident in the expression "not even the sky is the limit," found in the presentation to her YouTube channel.

As well as an identity and a lifestyle, low-income is also a state that should and can be altered, as in the following post:

You use the bankcard liked credit, but the money leaves the account immediately like debit. That way, it becomes easier to control your money. Because we're lowincome but want to be high-income, right?

Source io

$<$ https://www.instagram.com/p/BrTarBABoJk/?utm_source=ig_web_copy_link>

Making an appeal through the maxim "occupy all the spaces," BBR encourages her public to challenge the historical barriers to mobility in the country and make themselves present in situations once unattainable to the poor, like travelling by plane, studying for a degree or learning foreign languages.

One of the recurrent themes in the posts is financial education, seen as an essential element to achieve balanced expenditure and the desired economic upward mobility. Many posts contain practical advice on how to avoid becoming hostage to consumer impulses, avoid getting into debt and beginning to exert some effective control over spending. This also appears in hashtags like \#YourAccountYourRules. Advice includes writing down revenues and expenses in a notebook, getting an extra job, avoiding borrowing from loan sharks, taking a packed lunch to work, saving on electricity, drinking at home, and taking cold showers to reduce energy costs. The advice looks to fill a gap in the experience of her public: "We low-incomers were not financially educated. We're not used to talking about money, but we have to talk about the topic all the time. My mother is always out of control, she can't look at a card without using it, but that's how she was brought up, and after living like that for 40 years, it's difficult to change." ${ }^{\text {Io }}$

Managing expenses is identified as a central aspect of the social mobility project, as shown in the post below:

[If you earn $R \$ I, 000$ and spend $R \$ 999$, you're richer than someone who earns $R$ \$ IO, O०० and spends R\$ IO,OOI]

Financial education is the basis for LOW-INCOMERS to prosper.We're going to win for real! Educate yourself 


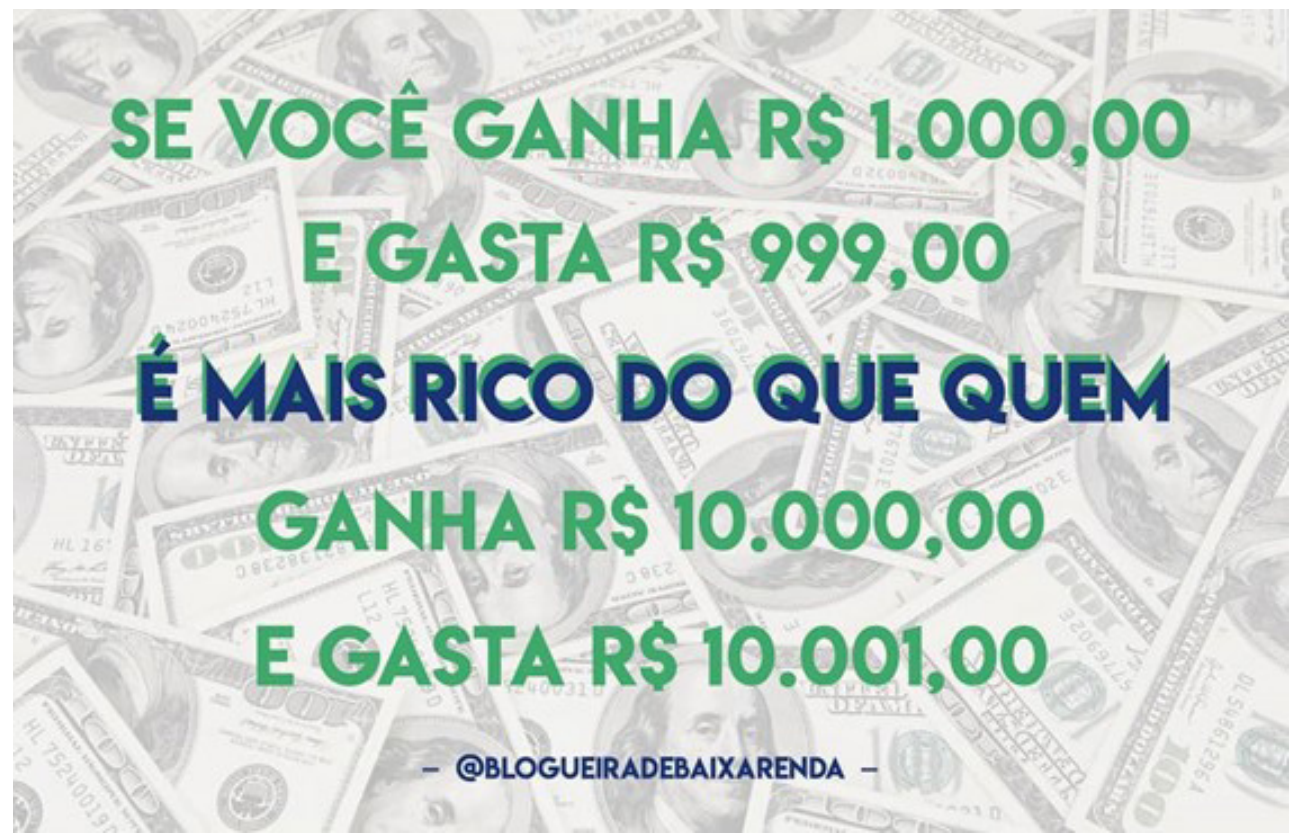

Figure 5

<https://www.instagram.com/p/BoN34skg3m6/?utm_source=ig_web_copy_link>

Financial education is articulated with the idea of overall administration of the everyday, including an appeal to rationality and self-control. To make this life project a reality, some tools, like a weekly planner, are presented to help plan and organize day-to-day activities.

Her commercial partnerships emphasize the same ethos of saving money and controlling finances. In partnership with the company Superdigitalapp, BBR produced a publipost advertising a physical pre-paid bankcard. Using this, clients spend only what is in their account, avoiding consumer impulses incompatible with their budget:

Superdigital prepaid bankcard. You only spend what you have in your account and don't end up in the red. LOVE IT! @superdigitalapp take me travelling again?

\begin{abstract}
AND MAY 2019 COME WITH NO DEBTS AND MANY TRIPS LIKE THIS ONE ש/,
\#YourAccountYourRules \#publi \#lowincomeblogger \#blogger \#25march \#purchases

Source

<https://www.instagram.com/p/Bq8KmTqByMY/?utm_source=ig_web_copy_ link>
\end{abstract}


An example of these guidelines for a balanced financial life is one of the videos with the highest number of views on her YouTube channel. In the clip, BBR teaches viewers how to teach make "smarter purchases" in the supermarket through a strategy she calls the "restocking method." This involves only buying products when they are running out, purchasing items every fortnight rather than monthly, for example.

Miller (2002) and Goidanich (20I2), in their ethnographic studies of supermarket purchases among middle-class housewives in London and Florianópolis, respectively, show how "spending" is, in fact, conceived as an act of "saving." Goidanich (20I2) recounts that consumers use the adjectives "conscious," "demanding," "moderate," "controlled" and "selective" in their selfdefinition as buyers. Miller's study shows how the act of buying, as well as revealing aspects of relationships, results in an expressive gesture of saving money. Saving strategies are related to moralities and the individual's wider identity, including class and reputation among other aspects (Miller, 2002: 22). In addition, saving does not necessarily imply buying cheaper items since an equation commonly present involves balancing low price and perceived quality. Miller calls attention to an important point: namely, that the desire to save needs to be examined in context, related, perhaps, in the London situation to aspects like modesty and aversion to excess.

In the Brazilian case, "spending" also results in "saving" as in British parsimony, but as a result of a major effort to control what are perceived as almost irresistible impulses to consume. At a primary level, "smart" purchases evoke a call for rationality in spending, acquiring products at a "good price" and, where possible, quality items. Going to the supermarket also functions as a sign of upward social mobility, such as when Nathaly remarks that she feels elated to be able to "buy a Danone, some cheese...," foods to which she had no access as a child.

The consumer education transmitted by BBR also includes a presentation of rules, etiquettes and conducts necessary to circulate in the new spaces opened up by social mobility. It is embarrassing not to know the rules to live new social situations, especially in a hierarchized society adverse to structural changes, built on the idea that "everyone has their place" (DaMatta, I98I).

LOW-INCOMERS ARE GOING TO TRAVEL ABROAD!

I DON'T KNOW WHEN BUT THEY WILL! BUT HOPEFULLY SOON, OKAY UNIVERSE? BECAUSE I'M EAGER TO GO, THANKS!

THAT'S IT, WE LOW-INCOMERS ARE THE MAJORITY, WHY AREN'T WE OCCUPYING ALL THE SPACES? LET'S OCCUPY!

Source

$<$ https://www.instagram.com/p/BxA7EXwBArX/?utm_source=ig_web_copy_link> 
In one of her YouTube videos, called "In the hotel in SP and a few more little purchases," BBR conducts a tour of the hotel room where she is staying in São Paulo during a work trip. She begins by advising viewers that the company paid for her and that she does not know how to "be chic." Next, she shows details of the hotel room, paying special attention to things seen for the first time, like the air conditioning unit embedded in the wall high up and the moveable TV screen. It amounts, then, to an apprenticeship in consumption for economically emergent groups, presenting the new places to be occupied with their specific rules and etiquettes.

From this perspective, social mobility should be actively pursued, eschewing a passive and fatalistic approach, as appears in the presentation on her YouTube profile: "How to win in a world in which, if you don't make your own opportunity, you have nothing." The search to join the world of work may not necessarily involve formal channels, since improvisation is one of the hallmarks of "low-incomers," as appears in her sayings: "poor people have to get by" or "so many things are possible, the poor are creative!" Whatever the case, life involves sweat and perseverance, and upward mobility should come through merit.

In an Instagram post, these elements are expressed in the photo showing the blogger on a hilltop, like a "heroine-warrior" on a magazine cover, reaching the desired summit. The symbolism of the broom, which in other contexts may be taken as a reference to devalued manual labour, appears here with the connotation of her own work that should not cause shame and will be recompensed with upward social mobility:

I'm ready to carry the salvation of the internet on my back $\theta$ LOW-INCOME ON TOP T⿱乛龰 Top Top Top 


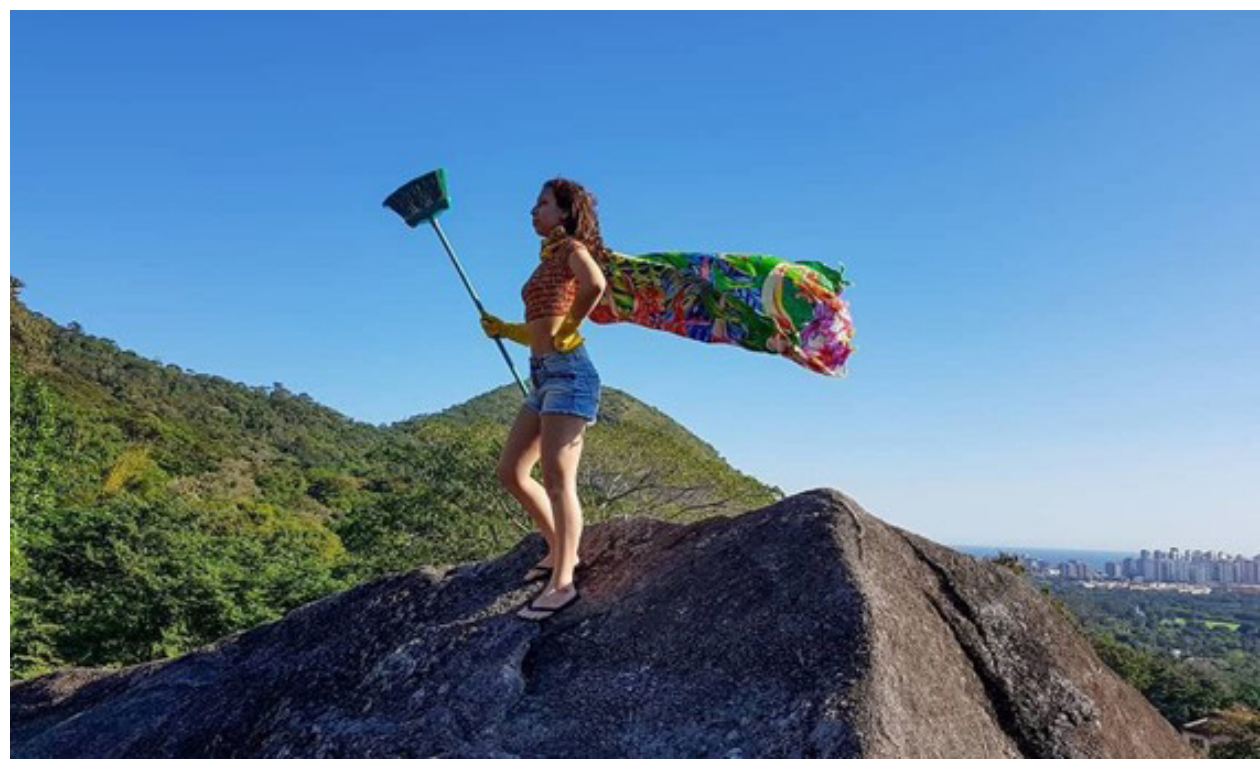

Figure 6

<https://www.instagram.com/p/BomE3MvgVwZ/?utm_source=ig_web_copy_link>

The words "overcoming" and "dream" appear at various moments, indicating the need for an active response to hardships, allied with the capacity to dream. In the posts, there is always a celebration when her dreams are realized, seeking to inspire her followers to take a similar path.

Various markers of social mobility appear in the profile, like living in a location separate from the family of origin, having a bank account, or enrolling in higher education. Along with financial control, priority is given to education as a privileged means to transform the condition of poverty. The increase in the level of schooling, expressed in the hashtag \#poorbutgraduated, is celebrated by the fact that the blogger belongs to the first generation of the family to gain a higher education diploma:

\section{WHO IS THIS STUDENT APPEARING ON THE TIMELINE, BRAZIL?}

As I would say myself: "education is the most precious wealth that we, Low-Incomers, can have." They can deprive us, they can take away everything, save our knowledge. And knowledge transforms. Mother always said: "daughter, study so that you don't end up like me" - and I studied not because I was scared to be like her, after all she makes me proud in so many ways - but because I want to give her what she truly deserves. And on this journey as a blogger, I found a teaching institution whose objective is to take knowledge to the most different and distant places: @eadunicesumaroficial.

Source

<https://www.instagram.com/p/B7UM2ykghSW/?utm_source=ig_web_copy_link> 
The space of the apartment is frequently the setting for her Instagram posts. At the start of her activities on the social network, BBR had just moved to the apartment that she considers to be her "true home," indicating a significant "life improvement" (Sarti, I996). The second publication on the social network is a photo of the door lock taken on the day of the move, where she thanks for "this victory as well."

Content showing spaces of the apartment is abundant, like the decorated bathroom door, the new carpet or the worktable:

A WOMAN WHO ASSEMBLES HER HOME OFFICE WITH MONEY FROM HER OWN WORK DOESN'T WANT A WAR WITH ANYONE $\boldsymbol{c}_{\boldsymbol{q}}$

Tomorrow is Thursday and video day on the channel... I told you a bit about how I began here on INSTAGRAM and showed you how I spent my first BLOGGER 'salary' :-8

Do you remember what you did with your first salary? Tell me in your comments!

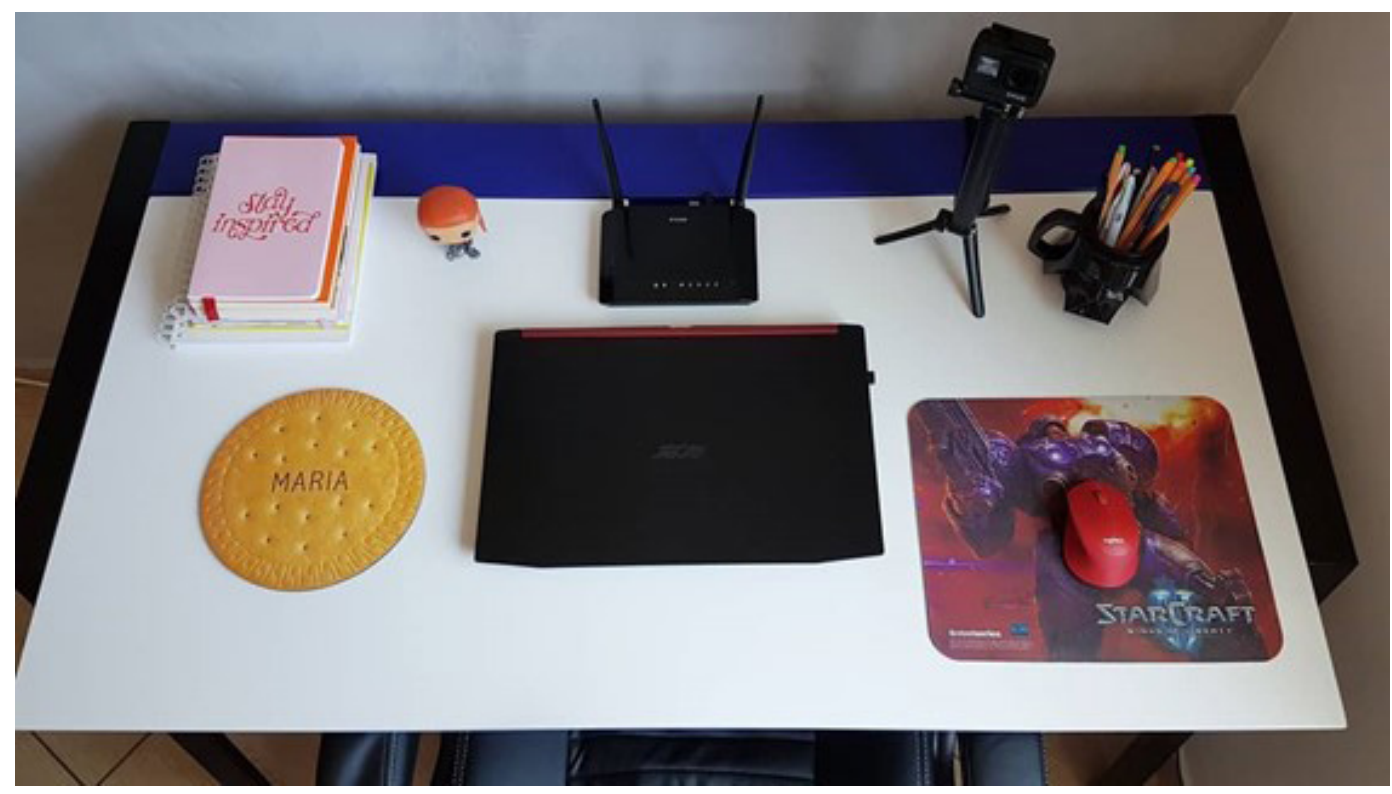

Figure 7

<https://www.instagram.com/p/Bvh2P5iBruo/?utm_source=ig_web_copy_link> 
The posts show the initially empty spaces followed by their occupation by objects, utensils, furniture, whether bought or donated, which formed part of the construction of the home. The sequences of photos and videos show the family history, the projects, the process of upward social mobility, and the tasks of maintaining and organizing the home. The elements of material culture are appropriated as part of the couple's trajectory in the process of decorating, since they are, as Miller (200I) declares, a "source and the setting of mobility and change."

\section{LOW-INCOME MINIMALISM}

In her choice of lifestyle elements to be propagated, BBR elects the dissemination of the minimalist lifestyle as one of her main missions on digital platforms, making a series of 23 episodes on YouTube called Minimalismo de baixa renda. The blogger tells her viewers that she became aware of the theme after watching the documentary Minimalism on Netflix. Researching the subject on the internet, she discovered that nobody talked about the issue to the low-income public - remarking, ironically, that poor people have always been minimalist without knowing - which persuaded her turn to produce this type of content.

The minimalist movement as a lifestyle (Meyer, 2004) first emerged among wealthier sectors of society, who always spent large amounts of their budgets on items as diverse as culture, leisure, hobbies, fashion and design. In the field of consumption and lifestyles, minimalism involves living with less items, enjoying "experiences" more than "things," expressed in the hierarchical superiority of "being" over "having." It also incorporates elements of sustainable consumption, with a stance against the irresponsible use of natural resources and the decision to support "fair," solidary and ethical means of production and distribution.

Thus, the minimalist lifestyle proposes a re-evaluation of life priorities that entails discarding surplus things, whether in terms of consumption, relations, ideas or activities that are not adding "value" to the person's life. Innumerable bestsellers have been published along these lines, like the book The joy of less: a minimalist guide to declutter, organize, and simplify, cited by Nathaly Dias as one of her own sources of inspiration.

Consumption thus comprises one of the main topics of conversation in this lifestyle. To incorporate the ethos, it is essential to resist senseless desires for purchases, which can lead to an overflow of goods that fills the home with products seldom if ever used. A distinction is made, therefore, between the "necessary" and the "superfluous" - associated here with irrationality, waste and ostentation - which informs everyday practices of acquiring, using and discarding goods.

The idea of "low-income minimalism" advocated by BBR involves redefining life priorities, strategies of financial education, ecological awareness, 
and new attitudes towards commodities. In her words, "minimalism means bringing out what makes you happy," in the sense of a re-evaluation of values with the aim of "valorising people and moments more than goods." These are the general principles of the minimalist lifestyle, founded on the idea of "less is more," as adopted on the BBR profile. It is worth stressing that these precepts need to be read from somewhere other than the middle and elite classes of the society where the movement originated, observing its local specificities.

The series of videos on minimalism shows actions like donating books to a neighbourhood public library and transforming the wardrobe by eliminating surplus items. In an interview, ${ }^{\text {II }}$ Nathaly ponders that it is very difficult for poor people to adopt the philosophy of "less is more" because when you get an income rise, you want to buy everything you always wanted. She cites the example of her mother who "despite being low-income has a load of pots." Her intention, therefore, is to "raise the awareness" of poor people that they do not need to have everything they want, escaping the persuasive campaigns of the marketing industry.

Another divergence from the experience of minimalism among wealthier sectors is that in the context of BBR, the adoption of this lifestyle is articulated with a project of upward social mobility. Spending less to spend better, not succumbing to debts, and avoiding "superfluous" consumption are all actions that contribute to achieving social mobility. Defining priorities and spending on what possesses "value" means reorienting expenses towards actions like paying for a professional training course, or buying clothes seen as "suitable" for circulating in new workspaces.

BBR's minimalism places considerable emphasis on the home space. In the second episode of the series "Low-income minimalism," called "Tour of the minimalist apartment," she shows "before" the reorganization of the home to be implemented with the help of minimalist precepts. All the rooms are shown with comments about the furniture, the division of spaces and the actions that will be taken with the adoption of the new lifestyle. "We already feel detached from the physical space," she remarks at one point of the video. The perception is that the organization of the home governs the way in which one lives and reflects historical and family trajectories: an aesthetic and identity-laden space, imbued with a lifestyle (Miller, 200I).

\section{CULTURAL MEDIATION AND CHANGE}

Analysis of the BBR profile on social media sites evokes the idea of cultural mediation, a theme of major importance in modern-contemporary society since it allows the transit and contact between distinct universes in a scenario of sociocultural heterogeneity and the diversification of social roles. Velho and Kuschnir (200I) examine this phenomenon, emphasizing that individuals immersed in the urban environment are exposed to a wide range of experiences 
as they circulate through universes with distinct and sometimes conflicting values and worldviews in which power relations are also at work:

Social life only exists through differences. It is these differences that, through interaction as a universal process, produce and enable exchanges, communication and interchange. The study of mediation, and specifically mediators, allows us to observe how interactions occur between distinct social categories and cultural levels. [...] In a ongoing process of negotiating reality, choices are made, taking symbolic systems, beliefs and values as frameworks of reference surrounding all kinds of material objectives and interests. Mediation is a permanent and not always evident social action, present in interactive processes at the most varied levels (Velho \& Kuschnir, 2001: 9-10).

Some individuals, transiting through different social dimensions, can become mediators between distinct worldviews, lifestyles and social experiences. Nathaly Dias's trajectory spans from her origin in a family with a low level of schooling to her entry into university, where she has contact with new forms of cultural capital, enabling her to deal with codes different from her original environment. In the process, BBR confronts new rules, habits, tastes, aesthetics and behaviours in a space of constant negotiation of reality, where she acts as a cultural mediator, promoting the exchange of information between symbolic systems, values and worldviews.

As Duarte (I986) proposes from a relational viewpoint, there is a discontinuity between the individualist ideology and the ethos dominant among popular classes, marked by traditional references like the pre-eminence of religion, family and kinship as spheres encompassing the individual dimension.

With the economic rise of groups at the base of the pyramid, especially during the two Lula governments (2003-20I0), there has been an observable increase in the level of schooling of children from popular families, including the emergence, in many cases, of the first generation of members with access to university. The same family environments started to be shared by people with significant differences in terms of their educational experiences and their cultural, social and symbolic capital (Bourdieu, I979b). While the popular consumption discussed in some of the studies cited earlier appears in its "excesses" and in the emphasis on increasing the number of material possessions, the case of BBR reveals another meaning, the conscious limiting of consumption as part of a new "minimalist" lifestyle. The transition between two worlds provides BBR with access to repertoires previously confined to middle- and upperclass sectors who chose to adopt a new relationship to material culture after an experience of intense consumption. This reveals, then, the dynamism of cultural mediation, blurring the boundaries between distinct social groups. As Velho and Kuschnir (200I: 27) have argued, cultural mediators can become agents of change as they negotiate between diverse and sometimes conflicting universes. 
The article thus calls attention to the plurality of meanings relating to consumption among the popular classes in a situation where the ways of dealing with materiality contrast with other low-income contexts in which the profusion of goods is actively pursued. The phenomenon of consumption has a central place in the BBR profile, appearing in diverse contexts such as in the curating of purchases, strategies for acquiring goods, and cataloguing both purchased and desired items. Financial education and the vision of "low-income minimalist" point to a new attitude towards consumption, enabling a more "rational" organization of budgets, an element driving socioeconomic mobility. The "occupation of spaces" called for by BBR appears with content relating to lifestyle, seeking to contrast with the opulence conveyed by other digital influencers present on Instagram. The encouragement of social mobility is opposed to a fatalistic position in relation to poverty, more widely present in a hierarchical context defined by a Catholic tradition. In BBR's case, the emphasis is on an appeal to individual awareness, rationality, self-control and proactivity, within a more individualist spectrum (Dumont, 1972).

As Miller (200I) argued, the lack of possessions does not imply that social actors have no agency over material goods. He suggests that materiality may have more value among the poor because they depend on few possessions to create cultural meanings. Along the same lines, Taylor (2013: 172) argues, in an ethnography conducted in the Dominican Republic, that "the materiality of the poor is not necessarily a materiality of poverty." Material forms are a way of combatting social stratification, explaining their enormous significance among these sectors of the population. The relation with material culture, without ignoring the influence of the huge economic difficulties confronted by the poorest groups, generates social change and builds futures.

Received on 25/May/2020 | Revised on I4/Sep/2020 | Approved on 08/Oct/2020

Carla Barros is a postdoctoral researcher at University College London. She gained her PhD from the COPPEAD-UFRJ Institute, having studied Social Anthropology at the National Museum (UFRJ) with an undergraduate degree in Social Sciences at IFCS-UFRJ. Professor on the Postgraduate Program in Communication at Fluminense Federal University (PPGCOM$\mathrm{UFF}$ ), her main area of interest is the anthropology of consumption, focusing on the popular classes. Her main publication is "Collective uses of mobile phones in the global South: cultural diversity among low-income groups in Brazil and in South Africa." 


\section{NOTES}

I The term "post" is used in this article as a synonym for a publication made by the owner of a social media profile.

2 Data from February 2020.

3 A digital influencer is a producer of content who utilizes their online channels (principally blogs and social networks) to "influence behaviours," both on the internet and beyond.

4 As well as Nathaly Dias, other content producers emerged who disseminated the everyday life of women from poor communities of Rio de Janeiro, like Nathalia Rodrigues (Nath Finanças profile), who provides financial advice to poor people, and Ana Helena Ernesto (Helena Pisponelly profile), who publishes re-enactments of her arguments with her mother on the YouTube channel Marilene não se mete (Marilene stay out of it) with the Maré favela as a background.

5 The miniseries can be found at: <https://www.instagram. com/p/B2fhTV8AwuI/?utm_source=ig_web_copy_link $>$.

6 The YouTube video can be found at: <https://www.youtube.com/watch?v=iFuj7yaF-Mk)>.

7 'Guanabara Anniversary' refers to the anniversary of the Guanabara supermarket chain present in the State of Rio de Janeiro. This well-known promotional event of the Rio retail trade typically draws more than a million consumers to its stores to take advantage of the huge discounts offered on products. In this period, traditional media and social networks publish photos and videos showing packed supermarkets, queues waiting for the stores to open, and, in some cases, heated disputes over the discounted products.

8 As is common in images of meals on the profiles of other lifestyle influencers, a photo is published of the dish taken from above without showing anyone eating. On the BBR profile, comments frequently praise the meals as examples of good home cooking.

9 Source:<https://www.instagram.com/p/Bm3kkz2BDb4/ ?utm_source=ig_web_copy_link $>$.

Io Interview available at: <https://www.uol.com.br/universa/ noticias/redacao/2019/o8/r2/blogueira-de-baixa-rendanathaly-e-pobre-e-ensina-minimalismo-no-youtube.htm>. 
II Source: <https://www.uol.com.br/universa/noticias/redacao/20I9/o8/I 2/blogueira-de-baixa-renda-nathaly-e-pobre-e-ensina-minimalismo-no-youtube.htm>.

\section{BIBLIOGRAPHY}

Barbosa, Livia. (2006). Cultura, consumo e identidade: limpeza e poluição na sociedade brasileira contemporânea. In: Barbosa, Livia \& Campbell, Colin (eds.). Cultura, consumo e identidade. Rio de Janeiro: FGV, p. I07-I38

Barbosa, Livia. (2004). Sociedade de consumo. Rio de Janeiro: Jorge Zahar Ed.

Barros, Carla. (2015). Consumo, gosto e materialismo digital na rede social Pinterest. In: Borges, Sílvia; Pinto, Michele \& Dubeux, Veranise. Consumo e sociabilidades: espaços reflexões. Rio de Janeiro: E-papers, p. 51-70.

Barros, Carla. (2007). Trocas, hierarquia e mediação: as dimensões culturais do consumo em um grupo de empregadas domésticas. Tese de Doutorado. Coppead/Universidade Federal do Rio de Janeiro.

Bourdieu, Pierre. (I979a). La distinction: critique sociale du jugement. Paris: Minuit.

Bourdieu, Pierre. (1979b). Les trois états du capital culturel. In: Actes de la recherche en sciences sociales, 30, p.3-6.

Campbell, Colin. (200I). A ética romântica e o espírito do consumismo moderno. Rio de Janeiro: Rocco.

Castro, Ana Lúcia. (2016). Sentidos do consumo e fronteiras simbólicas: uma etnografia entre grupos de baixa renda em um município da Grande São Paulo, Brasil. Etnográfica, 20/I, p. IOI-II7.

DaMatta, Roberto. (I98I). Carnavais, malandros e heróis: para uma sociologia do dilema brasileiro. 3 ed. Rio de Janeiro: Zahar Ed.

Douglas, Mary. (1976). Pureza e perigo. São Paulo: Perspectiva. Duarte, Luiz Fernando D. (1986). Da vida nervosa (nas classes trabalhadoras urbanas). Rio de Janeiro: Zahar Ed.

Dumont, Louis. (1972). Homo hierarchicus. Paris: Gallimard. Flick, Uwe. (2004). Uma introdução à pesquisa qualitativa. 2 ed. Porto Alegre: Bookman. 
Goidanich, Maria Elisabeth. (2012). Mamãe vai ao supermercado: uma abordagem etnográfica das compras para o cotidiano. Tese de Doutorado. PPGICH/Universidade Federal de Santa Catarina.

Kopytoff, Igor. (2008). A biografia cultural das coisas: a mercantilização como processo. In: Appadurai, Arjun (ed.). A vida social das coisas: as mercadorias sob uma perspectiva cultural. Niterói: Eduff.

Machado da Silva, Luiz Antonio. (2002). A continuidade do "problema da favela". In: Oliveira, Lúcia Lippi. Cidade: história e desafios. Rio de Janeiro: FGV/CNPq, p. 220-237.

McCracken, Grant. (1988). Culture and consumption. Indiana: Indiana University Press.

Meyer, James. (2004). Minimalism. New Haven: Yale University Press.

Miller, Daniel. (2002). Teoria das compras. São Paulo: Nobel. Miller, Daniel. (200I). Home possessions: material culture behind closed doors. London: Bloomsbury Publishing.

Miller, Daniel. (1987). Material culture and mass consumption. Oxford: Basil Blackwell.

Miller, Daniel \& Slater, Don. (2004). Etnografia on e off-line: cibercafés em Trinidad. Horizontes Antropológicos. Porto Alegre, Io/2I, p. 4I-65.

Moura, Iara. (20I5). Mulheres com classe: mídia e classe social em um Brasil em ascensão. Dissertação de Mestrado. PPG$\mathrm{COM} /$ Universidade Federal. Fluminense.

Rocha, Everardo. (1985). Magia e capitalismo: um estudo antropológico da publicidade. São Paulo: Brasiliense.

Sahlins, Marshall. (I979). Cultura e razão prática. Rio de Janeiro: Zahar Ed.

Sarti, Cynthia. (I996). A família como espelho: um estudo sobre a moral dos pobres. Campinas: Autores Associados.

Scalco, Lucia \& Pinheiro-Machado, Rosana. (2010). Os sentidos do real e do falso: o consumo popular em perspectiva etnográfica. Revista de Antropologia, 53/I, p. 32I-359.

Silva, Sandra Rúbia. (20Io). Estar no tempo, estar no mundo: a vida social dos telefones celulares em um grupo popular. Tese de Doutorado. PPGAS/Universidade Federal de Santa Catarina. 
Simmel, Georg. (1957). Fashion. American Journal of Sociology, 62/6, p.54I-548.

Slater, Don. (2002). Cultura do consumo e modernidade. São Paulo: Nobel.

Taylor, Erin B. (2013). The materiality of poverty: how the poor transform their lives. Plymouth, UK: Rowman \& Littlefield Publishers.

Valladares, Lícia. (2005). A invenção da favela. Do mito de origem à favela.com. Rio de Janeiro: FGV.

Veblen, Thorstein. (1965). A teoria da classe ociosa. São Paulo: Pioneira.

Velho, Gilberto \& Kuschnir, Karina (eds.). (200I). Mediação, cultura e política. Rio de Janeiro: Aeroplano. 
Palavras-chave

Estilo de vida; grupos populares; consumo; mobilidade social; minimalismo.

Keywords

Lifestyle; low-income groups; consumption; social mobility; minimalism
NEM O CÉU É O LIMITE: SENTIDOS DO CONSUMO E DINÂMICAS DE MOBILIDADE SOCIAL NO PERFIL @blogueiradebaixarenda NO INSTAGRAM E YOUTUBE

\section{Resumo}

O artigo aborda os sentidos do consumo no perfil @blogueiradebaixarenda nas redes sociais online Instagram e Youtube, considerando as percepções presentes acerca da materialidade e suas articulações com dinâmicas de mobilidade social. Trata-se de analisar quais elementos compõem o "lifestyle baixa renda" enquanto categoria nativa, dentro do contexto dos "influenciadores digitais". Mediante pesquisa de observação online, foram analisadas publicações, hashtags e comentários nas duas plataformas, explorandose de que modo as práticas de consumo aparecem como mediadoras de dinâmicas de hieraquização social e construções identitárias. Dentre os resultados, destacam-se as articulações entre materialidade e mobilidade social, a ideia de minimalismo dentro do "lifestyle baixa renda" e o lugar da blogueira como mediadora cultural.

\section{NOT EVEN THE SKY IS THE LIMIT: THE MEANINGS OF CONSUMPTION AND THE DYNAMICS OF SOCIAL MOBILITY ON THE @blogueiradebaixarenda PROFILE ON INSTAGRAM AND YOUTUBE}

\section{Abstract}

The article sets out to explore the meanings surrounding consumption on the @blogueiradebaixarenda profile on the Instagram and YouTube online social networks, considering the perceptions of materiality and their articulations with the dynamics of social mobility. It analyses the elements making up the "low-income lifestyle" as a native category within the context of "digital influencers." Through online observational research, the posts, hashtags and comments on both social media platforms were analysed, seeking to explore how consumption practices appear as mediators of social dynamics and identity constructs. Among the results, the articulations between materiality and social mobility, the idea of minimalism within the "low-income lifestyle" and the blogger's status as a cultural mediator are highlighted. 